\title{
THE QUALITY CONTROL SYSTEM FOR THE FINANCIAL AUDIT IN ROMANIA AND SPAIN
}

\author{
Sorin Briciu ${ }^{l}$ \\ Ioana Iuliana Pop (Grigorescu $)^{2}$
}

\begin{abstract}
Along the study we have realised a comparative analyses of the particularities of the quality control system particularities of the financial audit in Romania and Spain.

At the beginning of the paper we have presented the evolution of the quality control systems of the two countries, after which we have compared the International Audit Standards referring the quality control applied in Romania and the Technical Norms of Audit referring the quality control in Spain, identifying a series of differences between these. Next we have realised a comparative analyses of the particularities of the quality control systems in the two countries, based on which, at the end of the paper we have made some improvement proposals.

We have used qualitative research methods, such as describing, analyses and comparison. The obtained conclusions come to sustain the hypothesis that in Romania and Spain have been made important steps in adopting the regulations of the European Directives referring the financial audit concerning the quality control, so that the juridical frame and the professional one of the two countries presents several similitude, the differences being less significant.
\end{abstract}

Key words: the internal quality control system, the public surveillance system of the financial audit activity, the quality control at the mission level, the quality control at the firm level, the objectives of the inspection of the quality control.

JEL Codes: $M 42$

\section{Introduction}

The quality mustn't be seen as a negative thing, as something legal but as an adequate and necessary task to obtain quality audit missions and efficacy in the audit cabinets.

The hypothesis from which starts this research is the fact that in Romania and Spain have been made important steps in adopting the reglementations of the European Directives referring the financial audit regarding the quality control, so that the juridical and professional frame of the two countries present several similitude, the differences being less significant.

To demonstrate this hypothesis, as objectives we have proposed to determine the way in which have been adopted the regulations of the European Directives concerning the quality control system regarding the financial audit in the Romanian and Spanish legislation, to realise a comparative analyses of the particularities of the quality control system of the financial audit in the two countries. Furthermore we will try to identify possibilities of improving the quality control systems of the financial audit from Romania and Spain.

The reasons for which we have chosen Spain for the research is that it is a member state of the European Union having a longer tradition tan Romania in audit. In this country the part of the professional organisations is well defined, the professional interests of the auditors being better

\footnotetext{
1 „1 Decembrie 1918” University of Alba Iulia, Romania, e-mail: briciusorin@gmail.com

2 “1 Decembrie 1918” University of Alba Iulia, Romania; cotutoring Lleida University Spain, e-mail: ioanaiuliana69@yahoo.es
} 
protected fact that could be interesting for Romania too. Moreover, the starting point of our analyses has been observing the differences between the internal and external quality systems in the two countries.

\section{The research Methodology}

The research Methodology is a qualitative one. To demonstrate the hypothesis and obtaining the proposed objectives we have realised a documental research referring to documents such as: Directive 2006/43/EC, the quality control legislation of the financial audit in Romania and Spain (the International Audit Standards referring the quality control applied in Romania and the Technical Norms of Audit referring the quality control in Spain), electronic relevant data basis ( CAFR, ICAC sites or some public institutions in Romania and Spain), the national and international specialty literature ( manuals, books, specialty articles).

The used techniques to centralise the information have been the critical evaluation of the documents, systematization, comparison and analysing the obtained information. As a work method I have used the synthesis papers, the ideas plan and the informative summary. The basic procedure was to table the data so that as a result of comparing and analysing them, to be able to formulate useful conclusions.

Therefore I have realised a descriptive research, by the help of which I have briefly presented the evolution of the quality control systems of the financial audit in Romania and Spain and a critical description of the actual situation. The comparison was at the basis of all the researchit referring to the situation of the quality control systems in Romania and Spain, permanently referring to the Directive 2006/43/EC.

In order to reach the second objective, that of realising a comparative analyses of the particularities of the quality control system of the financial audit of the two countries not only I have studied the simple description of the present situation but also I have tried to analyse and explain the found differences and resembling, their causes and implications.

At the end of the paper I have concluded if the emitted hypothesis has been demonstrated and I have tried to propose some improvement measures of the quality control system in the two countries.

\section{Revising the specialty literature}

The Spanish specialty literature contains a higher number of comparative studies about the financial audit with different countries from Europe- England, Portugal, the group of the first 12 members of Europe and countries from the Latin America. They have been realised years ago and do not surprise the new elements introduced by the Directive 2006/43/CE.

Concerning the comparative analyses of the systems of quality control, we have noticed the preoccupation of the different authors, in the specialty literature magazines in Spain to analyse the International Quality Control Standard, as it will soon be compulsory in this country. Here we could remind some authors' studies Maria Antonia García Benau (2011), García Delgado Sonia and Izaskun Ipiñazar Petralanda (2011), Uyarra Encalado Esteban (2011) as they appear at the end of the paper in the bibliography. We think that it is important to analyse the impact that it had the European harmonising process on the auditors and audit firms, in a new context, that of the world crises, enriching the specialty literature with new perspectives.

In our country my research brings something new, because of the fact that in present, in the Romanian specialty literature there is no comparative study between Romania and any other European country, which analyses the degree of adapting the legislation concerning the financial audit to the European Directives, and less comparative studies with other national systems of quality control in Europe. 
This way this paper has a theoretical importance, meaning the fact that it helps to discovering new ways of approaching, similitude and differences between the compared elements, which lead to discovering possible solutions.

From the practical point of view, the comparative studies approach concrete problems which preoccupy the auditors in this transition époque and economic crises. The audit firms' small and middle ones do not have time and the necessary founds to realise this type of researchmoreover to the international level. They can lead to identifying the common problems from the national and international ambits', and improving the services offered by the auditors, to promoting the professional interests, developing the profession and promoting the good name of the financial audit.

\section{The evolution of the quality control systems in Romania and Spain}

The quality control systems do not have a very long tradition. In Europe around 1996 appears the Green Book named "The function, position and the civil responsibility of the legal audit in EU". Based on conclusions after analysing it, in 1998 the Audit Committee emits the document called "The Legal Audit in EU- the way to follow", in which one of the main themes refers to analysing the quality control audits realised in the EU member states.

Next, in 2000 it was published "The quality control legal audit - minimum conditions", in which it was shown the fact that "In this moment there isn't any norm to define minimum conditions of quality control" and that initiative" pretends to establish a reference frame for the systems of quality control for all the member states in EU'.

In 2003 it is emitted the communication "The audit's part in EU", and in 2006 the Directive 2006/43/CE in which it is shown that "the regular inspections represent a good environment to obtain a high and homogeny quality" Therefore the legal audit" has to be connected to a quality control system which has to be organised separately".

The Enron or Worldcom case from the United States, Gescatera from Spain or Parmalat from Italy have shaken the credibility in the accounting audited situations, so that it is more than necessary implementing a quality control system for the financial audit."Why is there necessary to be a unique audit market, if there is no guarantee that the done legal audits resent the same quality level, no matter the member state that the auditor is part on"(Garcia Delgado and Ipiñazar Petralanda, 2007).

In this context it is emitted the Directive 2006/43/CE which in the VIth chapter called "Quality assurance 'states that "all the auditors are part of a uniform system of quality assurance with the purpose of enriching the public trust in the audit function". In chapter VIII the directive states tasks regarding the public surveillance of the legal auditors and audit firms. The states "must organise an efficient system of public surveillance" whose object is represented by "all the legal auditors and audit firms". The tasks of the Directive have been introduced in the national legislations of Romania and Spain this way:

In Romania have been approved O.U. 90/2008 which in article 6 refers to the system of quality assurance and the criteria they had to fulfil. Also, in Title II, chapter 12 it is stated the way of functioning of the Public Surveillance Council of the Statutory Audit Activity.

In 2010 appears the Law 26 regarding the financial audit activity, which in chapter VII establishes that CAFR activity develops under the guidance of the Public Surveillance Council of the Statutory Audit Activity.

In Spain has been approved the Law 12/2010 which states the Directive2006/43/CE that all the auditors and audit societies are to be controlled by a public control system, objective and independent, under the ICAC (The Accounting and Audit Institute in Spain) leading. The law 
12/2010 has been erased and replaced with TRLAC 2011 (The revised text of the Financial Audit Law), which dedicates the whole chapter VI to the public control system of the financial audit.

\section{The internal and external quality control system in Romania}

In Romania quality control system has two different parts: internal quality control system of the audit firms and the external quality control system made on it.

\section{The internal quality control system}

In Romania it is reglemented by two different standards:

- ISQC1 - refers to the quality control system which makes audits and revises for financial situations and other assurance missions and side services;

- ISA 220 - refers to the quality control at the mission level, for an audit at the financial situations.

In order to obtain quality audit missions firstly has to be implemented at the level of the audit firm ISQC1, and then ISA 220.

The International Standard regarding the quality control (ISQC1) establishes the responsibilities of an audit firm to make its own assurance system and quality control also the instruction way and maintenance of this system. It is also applied in Romania starting December 15th 2009, for all the services aligning the Standard for IAASB missions meaning: the International Standards of Audit (ISA), the International Standards for revising missions (ISRE), the International Standards for assurance missions (ISAE) and the International Standards for side services (ISRS).

The purpose of this standard is that the audit firm to obtain a ,"'reasonable assurance" about its conformity and firm personnel with the professional standards and also with the legal norms and emitting adequate circumstantial reports. According to ISQC1 the quality control system of an audit firm will contain the following elements: the leaders responsibility regarding quality at the firm level, ethics tasks, accepting and continuing the clients relations and specific missions, the human resources, realising the missions, monitoring the politics and quality control procedures and documentation of the quality control system.

ISA 220 "Quality control for an audit of the financial situations" has as target obtaining by the audit firm of a "reasonable assurance" about its conformity and emitting some adequate reports to the circumstances. It refers to the realised activity at the audit mission's level and has the following basic elements: the management responsibilities for the quality of the missions, nominating the missions teams, developing the missions, monitoring the activity and wring the documentation according to the identified problems.

\section{The external quality control system}

In Romania the revise activity of the quality for the financial audit activity develops according to: O.U.G. 75/1999, O.U. 90/2008, Law 26/2010, The organising and functioning of the Financial Auditors Chamber in Romania, and the Norm from August 25th 2010 regarding the revise of the financial audit activity and other activities developed by the financial auditors, approved by the Financial Auditors Chamber Council Decision nr. 168/2010.

The Norm from 2010 shows that the Monitoring and professional Competence Department (DMCP) from CAFR "makes checking to assure quality". CAFR is "the competent authority to make revise in order to assure the quality of the services made by the financial auditors" and develops its activity under the surveillance of the Public Surveillance Organism for the Financial Audit Activity. The norm shows that, "all the financial auditors members of the Chamber, physical persons and audit firms, make the object of an assurance system of the quality". 
The necessary resources to realise the checking by DMCP are assured by the CAFR, by the annual budget of incomes and expenses. The effective checking is realised by inspectors and assistant inspectors, employees for the executive apparatus of the Chamber.

Among the objectives of the control inspection of the quality control activity for the financial audit stipulated in the III rd chapter of the 2010 Norm we can remind:

- knowing the area of the activity for the financial audit of the inspected firm;

- Checking the activity conformity developed with the declaration for obtaining the authorisation of the profession;

- Checking the implementation of a system of internal quality control system in conformity with ISQC1 and ISA 220;

- The evaluation of the internal assurance of the quality in conformity with ISA and the tasks of the Ethic Code;

- Inspecting the work sheets for the audit missions;

- Checking the implementation of some specific procedures applicable to some specific procedures applicable to the clients as to prevent the operations of money washing or financing the terrorism acts;

- Evaluating the content of the most recent published Transparency Report, etc.

The revising procedures to ensure the quality are elaborated by DMCP in lists for inspections objectives, on missions, which are presented to being approved by the Chambers Council and advised by the Public Surveillance Organism. The planning will be made so that every member of the Chamber to be inspected minimum once in six years, or once in three years in the public interest auditors 'case, those being announced in writing that they are to be inspected and also notified about the period which is proposed for checking.

At the end of the inspection it is written the inspection Note, which is a bilateral document between the inspectors' team and the inspected auditor. It is recorded by the auditor and the Chamber. Every objective from the list of objectives will be filled in with YES or NO. Based on DMCP it will be established a percentage between $0 \%$ y $100 \%$, obtained by reporting the number of objectives for which the answer was affirmative to the total number of objectives. This percentage will lead to obtaining the marks this way:

- Up to $35 \%$ - D mark;

- From $36 \%$ to $70 \%$ - C mark;

- From $71 \%$ to $85 \%$ - B marks;

- From $86 \%$ to $100 \%$ - A mark.

The auditors who have obtained D, C and B marks are monitored during three consecutive inspections by the Chamber, to establish measures to remediate nonconformities or applying disciplinary sanctions.

Article 29 of the Norm from 2010 describes the measures which will be taken during the three consecutive measures, according to the obtained grade. When it is unsatisfactory for the bad quality of the activity developed by the financial auditors, this will be published by the Chamber's media.

DMCP inspectors "have the quality of employees inside the executive apparatus of the Chamber". They have to fulfil a series of conditions: to have professional preparation and relevant experience in the statutory audit, specific preparation in the quality inspections field, to be independent and not to be in the interest conflict with the financial audited inspected.

The inspectors must sign annually a conformity declaration with the professional tasks of the Chamber, regarding the quality control of the audit. The coordinators of the team and part of the members are auditors. 


\section{The internal and external quality control system in Spain}

The obligation of doing quality control audit work has a longer tradition in Spain. The Technical Audit Norms of General Character published by the Resolution from January 19th 1991 established the Obligation of maintaining a kind of quality level in doing the papers. Later in 1993 ICAC has published by the Resolution from March 16th the Technical Norm on Quality Control. This contains the majority of the fundamental principles of the internal control, specific to the audit activity, so that they can obtain the objectives which are to be fulfilled by the quality control system.

The entering into vigour of the new Directive 2006/43/CE, emitting the Recommendation of the European Commission in 2008 referring to the External Quality Control of the legal auditors and audit firms and the coming up of ISA clarified in 2009 forces the national legislations to adopt the new modifications.

In Spain, the approval of the Law 12 from June 30th 2010 has represented an important step harmonising the tasks at the European level. The article 5 of this normative act defines the juridical system for the financial audit activity. This system refers to the Law 12/ 2010 of the financial audit and to the Norms of Audit. They comprise the Technical Norms emitted in 1991, NIA adopted by EU, Ethical Norms and the Quality Control Norm.

In the year 2011 it is approved the Revised Text of the Law of the Financial Audit which replaces and erased the Law 19/1998 and the Law 12/2010. This new law establishes the fact by the term 'financial audit control'" we must understand two types of activities:

- The technical control activity - which is based on checking the audit missions or some aspects of this activity in order to evaluate if there have been respected or not the present audit norms. It is about a self checking which every audit firm must realise, by the help of some procedures to make sure that all the services that they offer to the clients fulfil all the legal norms. This self checking must refer to all the organisational aspects and also check: the Independence, continuous learning of the employees, accepting and continuity of some clients, the cooperation with independent experts, etc. The technical control represents in fact the INTERNAL control of quality.

- The activity of quality control - which implies the periodic revise of the auditors and of the audit firms with the purpose of improving the quality of the audit works. This activity supposes checking the internal control system or revising the documented procedures to evaluate the efficacy of the internal control system. This represents the EXTERNAL quality control. The internal quality control must be checked by someone independent, from outside the audit firm.

\section{1. The internal quality control system in Spain}

The auditors' obligation and the audit firms to dispose of an internal quality control is even more necessary once with entering into vigour of TRLAC (The revised text of the Financial Audit Law) and of the Regulation of its applying.

The third Technical Norm having a general character published by the Resolution from January 19th 1991 by ICAC asks for maintaining of a certain quality level in developing the audit Works, which was obtained by the realisation of some procedures established by the auditor, according to the organisational structure of the firm, with the purpose of assuring in a reasonable form, that the professional services which it offers fulfilment to the Technical Audit Norms.

After that ICAC emits the Resolution from March 16th 1993 by which it is published the Technical Norm on Quality Control (BOICAC 12/1993), which develop the auditor's obligation to implement an adequate internal quality control. After 1993 important changes have been made at the European and international level, both for external and internal quality.

The most important event was the appearance of the International Quality Control Standard ISQC 1 emitted by IFAC. 
In this moment in Spain ISQC 1 does not have a compulsory applying status, but it pretends a convergence at this standard in the near future. It is found in the stage of " implementing process" For this ICAC has emitted the Resolution from December $22^{\text {nd }} 2010$ where it becomes public the translated text of ISQC 1, under the name of Internal Quality Control Norm of the financial auditors and audit firms (NCCI). This Resolution makes public the Internal Quality Control Norm, by its publishing in the Official Bulletin nr. 84 from December 2010 of ICAC. Because of the novelty and complexity that it supposes, the auditors had a six months period when they could write their observations about the published norm. The same Resolution says that the auditors and the audit firms have to implement the internal quality control system according to NCCI before October 12th 2012.

During the six months period there have been presented observations at the published text, fact that has determined that ICAC to revise the text NCCI and to insert some modifications, which refer especially to auditors and audit firms of small sizes and to those that audit public interest entities. After that on October 26th ICAC emits another Resolution where it is published a new form of NCCI, where are being made modifications which are less substantial. Also, the most important fact is that it is modified the limit data for the firms to be compelled to implement the internal quality control system in the audit firms up to January 1 st 2013.

NCCI represents a translation of ISQC1, adapted to the Spain's characteristics where were eliminated all the references from the audit institutions from the public sector and to all the other distinct services to the financial audit, if they don't enter under the Law12/2010. Also, it was eliminated and replaced the implementing datum, being stipulated in the Resolution from 2010, and then with the one in 2011.

The ICAC Resolution from 2010 states that NCCI "replaces" the Technical Quality Norm from 1993, in vigour at the time. It is important to say that NCCI, which represents a translation of ISQC1, establishes the responsibilities of the leaders of the audit firm to make its own assurance and quality control at the firm's level.

The Technical Quality Norm from 1993as well as ISA 220 (Standard that Spain has not adopted yet) refers to implementing the quality control procedures by the auditor or the leader of the audit mission, at the level of a mission.

Therefore, ICAC and the Professional Corporations when doing the external quality control will evaluate the way in which the firm management has implemented and maintains the internal quality control at the firm level ( according to ISQC1 at the international level or according to NCCI at the Spain's level) and will evaluate the quality of the audit missions ( according to ISA 220 at the international level or the Technical Quality Norm from 1993 at the Spain level, which has been replaced by ICAC to NCCI by the Resolution from 2010).

The quality control programme initiated in Spain in 2010 was the beginning of a new cycle in the quality control activity. The differences between the two norms refer to the fact that NCCI is centred on evaluating the elements of the internal quality control system, describing, evaluating and revising of the procedures of this system and its applying in the audit missions by all the members of the team. Therefore NCCI goes further over the simple applying of the Technical Norms of Audit and check how the decisions have been made, how the quality control system of the firm works.

The majority of specialists from Spain appreciate as being very important the adjusting period to this new, "quality culture" and the fact that the auditors need time to reflect over changes, to exange impressions with their colleagues, to address to the Professional Corporations to clarify the doubts. Therefore, the entering into vigour of the norms was delayed until January 1st 2013. During 2011 the Professional Corporations have published orientate Guides (REA has published the Organising quality control Manual), have organised professional courses (ICJCE has created the 
Quality Department) with the purpose of helping its members in applying and implementing NCCI up to the end of 2012.

The tasks established by the internal quality control must comprise the following elements: leading responsibilities of the internal quality control, tasks of ethics applicable in relation with the independence principle, accepting and continuing the relation with clients, human resources, realising audit missions, monitoring the procedures and documenting the internal quality control system.

\section{2. The external quality control in Spain}

The external quality control in Spain has two components:

- The public supervise system and financial audit control activity made by I.C.A.C. (Accounting and Audit Institute) according to TRLAC 2011 and the Directive 43/2006/CE;

- The made control by the Professional Corporations to its members, in conformity to Internal Norms or the Status of these Corporations.

6.2.1. The public Supervise System for the quality control activity is being made by the General Subdivision of Technical Control from the Accounting and Audit Institute in Spain. This activity is reglemented in chapter IV of TRLAC, which transposes the Directives 2006/43/CE regulations.

If we refer to the public supervise and audit control, activity TRLAC in art. 27.3 And 27.4 indicates the responsibilities of this system: the authorising and enlisting the members in R.O.A.C. (Official Financial auditors Register in Spain), the continuous formation of its members, adopting the Ethics Norms, adopting the Internal Quality Control Norm, of Audit Technique, quality control, research system and sanctions applying.

I.C.A.C. can give control attributions to the Professional Corporations of the auditors or to some physical persons, selected as a result of an objective process.

The main purpose of the I.C.A.C. does not applying sanctions but quality improving of this activity. The controls ending can be formative- when are accepted the recommendations, or disciplinary - when the sanctions are applied, as the observed deficiencies are not corrected.

In art. 28.2 of TRLAC it is shown that ICAC can be asked to the auditors or to the audit firms can ask the auditors or the audit firms which are controlled the necessary information, or may be done as many inspections and investigations as necessary to reach the proposed aims. The auditors and audit firms cannot refuse it as art. $32 \mathrm{c}$ of TRLAC qualifies this as a serious crime.

For the years 2010 and 2011 ICAC has ended a cooperation convention with ICJCE, as to realise the quality control. The first Convention was signed in July 22nd 2010, and the second in April 12th 2011. For example for 2011 the revision period lasted from the signing datum till November 2011, as in the first days of December the quality revisions had to be finished, and the documentation sent ICAC.

Therefore have been named 10 revisers, who have all the conditions: they are not active auditors- meaning they do not do financial audit activities, are independent - meaning are not part of the firm which is to be controlled and are free of any possible influence or interest' conflict, have professional background and specific knowledge in the field of quality control.

In the year 2011 these have been selected by an evaluation Comision formed by representatives of ICAC and ICJCE. The first phase to evaluate the candidate merits, and the second phase was an interview. Among the basic conditions it can be specified: to be enlisted in ROAC at the "No exercises", minimum seven years experience as auditor and availability to travel.

In 2010 the used marks in the quality control Report was descending, the following: A1, A2, B $\square$ i C. Those who have obtained C mark have been sent to the National Deontology Commission. 

divided into:

In the year 2011 disappear all these grades, and the results of the quality control are

- without deficiencies - in the case of the firms or auditors where haven't been detected relevant deficiencies;

- with deficiencies - case in which a proposal is being made, a kind of an improvement

Plan, in which are also included recommendations to improve the observed deficiencies.

6.2.2. In Spain the Professional Corporations also have the obligation to realise quality controls for the activities realised by its members, with the purpose of assuring that they respect the present legal norms. For this they check the auditors work documents, but also they have to keep professional confidentiality and inform ICAC on the results of their control at the end of each year, making proposals to sanction where necessary.

7. A realization of the comparative analyses involving the particularities of the control system regarding quality between the financial audit in Romania and Spain.

Analysing the events in their chronologic evolution it can be noticed that in Spain, the Technical Norms of Audit having a general character and the Technical Norms on the Quality Control have been elaborated around 1991-1993, a post data to the appearance of the law regarding the financial audit in Spain and of coming into life of the Accounting and Audit Institute (ICAC), in 1998.

In Romania, as a result of the historical events, of the Revolution in 1989, the things have developed differently. The accounting specialists from Romania were eager to align to the international and European laws and started the activity of their admittance before the profession of financial auditor to be accepted (1999). Around 2000, with less than a year before coming into being of the Room of the Financial Auditors in Romania (CAFR), they pass to taking over the International Standards of Audit (ISA), which then in 2009 have been replaced with the International Standards of Audit clarified.

In Spain ISA have not been taken over, and after the appearance of the modified ISA and of the Directive 2006/43/CE has started the process of gradually taking over the clarified ISA and of ISQC1. Up to the present have been taken over only four clarified Standards, and ISQC1 has been translated and adapted and will enter into vigour starting with January $1^{\text {st }} 2013$.

As it can be noticed, the financial audit has become basic in Romania eleven years later then in Spain. Not being a law it has passed directly to taking over the International Standards of Audit.

In Spain, though the process started sooner we can notice a certain conservationism regarding introducing the changes. The process of implementing the Standards of Audit is extremely slow, with long pre-periods of public consulting.

Table no. 1

The particularities of the quality control system in Romania and Spain

\begin{tabular}{|c|l|l|}
\hline \multicolumn{3}{|c|}{ THE INTERNAL SYSTEM OF THE QUALITY CONTROL } \\
\hline & \multicolumn{1}{|c|}{ ROMÂNIA } & \multicolumn{1}{c|}{ SPAIN } \\
\hline $\begin{array}{l}\text { The basic } \\
\text { normative } \\
\text { documents }\end{array}$ & $\begin{array}{l}\text { - ISQC1 the quality control for the firms } \\
\text { which have audits and reviews of the } \\
\text { financial situations and for other missions } \\
\text { of assurance and side services }\end{array}$ & $\begin{array}{l}- \text { "N.T. regarding the quality control from } \\
\text { compulsory starting January 1st2013 }\end{array}$ \\
\hline
\end{tabular}




\begin{tabular}{|c|c|c|c|}
\hline & \multicolumn{2}{|c|}{$\begin{array}{l}\text { - ISA } 220, " \text { the quality control for an } \\
\text { audit of the financial situations"' ( the } \\
\text { control of the activity at a mission level) }\end{array}$} & $\begin{array}{l}\text { - NCCI ,"The International Norm of the } \\
\text { quality control" (adopted from ISQC1) }\end{array}$ \\
\hline $\begin{array}{l}\text { The data when } \\
\text { ISQC1 becomes } \\
\text { legal }\end{array}$ & \multicolumn{2}{|r|}{ December 15th 2009} & $\begin{array}{l}\text { Starting January 1st } 2013 \text { will be applied } \\
\text { NCCI, which represents a translation of } \\
\text { ISQC1, adjusted at the Spain characteristics. }\end{array}$ \\
\hline $\begin{array}{l}\text { For whom it is } \\
\text { applied ISQC1 }\end{array}$ & \multicolumn{2}{|c|}{$\begin{array}{l}\text { For all the services which are connected to } \\
\text { the Standards IAASB: } \\
\text {-audit missions (ISA) } \\
\text { - review missions (ISRE) } \\
\text { - assurance missions (ISAE) } \\
\text { - side services (ISRS). }\end{array}$} & For all the financial audit missions \\
\hline \multicolumn{4}{|c|}{ THE EXTERNAL SYSTEM OF THE QUALITY CONTROL } \\
\hline & & ROMÂNIA & SPAIN \\
\hline \multicolumn{2}{|c|}{$\begin{array}{l}\text { The basic normative } \\
\text { documents }\end{array}$} & $\begin{array}{l}\text { - Directive 2006/43/CE; } \\
\text { - O.U.G.75/1999; } \\
\text { - O.U. 90/2008; } \\
\text { - Law 26/2010; } \\
\text { - The regulation of organising and } \\
\text { functioning of CAFR; } \\
\text { - The norm from august 25th } 2010 \\
\text { regarding revising the quality of the } \\
\text { financial audit activity and of other } \\
\text { activities developed by the financial } \\
\text { auditors, approved by the Council's } \\
\text { Decision CAFR nr. 168/2010. }\end{array}$ & $\begin{array}{l}\text { - Directive } 2006 / 43 / \mathrm{CE} \text {; } \\
\text { The external system of the quality control in } \\
\text { Spain has two components: } \\
\text { - The public super-advising system of the } \\
\text { financial audit ruled by art. IV from TRLAC } \\
\text { and the regulation of applying TRLAC } \\
\text { approved by the real decretory nr. 1 from July } \\
2011-1 \\
\text { - The controls made by the Professional } \\
\text { Corporations. The three main corporations are: } \\
\text { - Instito de Auditores-Censores Jurados de } \\
\text { Cuentas din Spania (ICJCE); } \\
\text { - Registro de Economistas Auditores (REA); } \\
\text { and } \\
- \text { Consejo Superior de Titulares Mercantiles. }\end{array}$ \\
\hline
\end{tabular}

Source: self- processing

As what concerns the internal system of the quality control from the audit firms, in Romania it is ruled by the International Standards ISQC1 and ISA 220, translated into Romanian.

In Spain, ISQC1 which refers to the quality control at the level of the audit firms, this has been translated and adjusted at the national conditions and it is named The International Norm of Control of the Quality (NCCI). Its applying has started in 2010, when it has been published in the Official Bulletin of the State (BOE), but it has a compulsory only starting January $1^{\text {st }} 2013$.

In what concerns the quality control at the level of the audit missions we have noticed an inadvertence. The ICAC resolution from October 26th 2011 says that the Technical Norm from 1993 (equivalent to ISA 220 referring to the internal control of the quality at the audit mission's level), will be replaced with NCCI, which refers in fact to the internal control of the quality at the audit firm's level (the translated variant of ISQC1), which is not the same thing. My opinion is that the Technical Norm from 1993 which refers to the Internal Control of the quality at the mission level which has to remain into vigour up to its adjusting in Spain of ISA 220.

Another difference is represented by the fact that ISQC1 in Romania it is applied for all the services that apply to Standards IAASB (ISA, ISRE, ISAE, ISRS), and the International Norm of Quality Control in Spain (NCCI) refers only to the missions of financial audit. To my opinion, the norm which states the system of internal control of the quality should refer to all the services that the financial auditors offer, making the work easier this way. And I mean here especially the small audit cabinets, which should have a single Quality Manual, to impose this way a certain internal culture of the quality at the firm's level. 
The external system of the quality control is ruled at the European level by the Directive 2006/43/CE, but at the national level, the situation from Romania and Spain is quite different.

In Romania this system has only one component which refers to the System of Public Surveillance of the activity of financial audit. The activity of quality control is coordinated by the Department Of Monitoring and Professional Competence (DMCP) from the Chamber of the Financial Auditors from Romania, and the activity of surveillance of the Room is realised by the Organism of Public Surveillance of the activity of financial audit.

In Spain the system has two components:

- One refers to the system of Public Surveillance realised by the Accounting and Audit Institute (ICAC), according to chapter IV from the revised text of the Law of the Financial Audit (TRLAC) and the regulation of its functioning.

- The second refers to the control realised by the Professional Corporations (ICJCE, REA, and REGA) to its members, according to the internal norms or the status of these corporations. What is more to say is that starting 2010 these controls do not have a compulsory character.

The authors explain the differences between the two norms by the following table:

The particularities of the quality control in Romania and Spain

Table no. 2

\begin{tabular}{|c|c|c|}
\hline & ROMÂNIA & SPANIA \\
\hline $\begin{array}{l}\text { Who makes the } \\
\text { external quality control } \\
\text { checking }\end{array}$ & $\begin{array}{l}\text { Inspectors and assistant inspectors } \\
\text { from the Monitoring and } \\
\text { Professional Competence } \\
\text { Department from CAFR }\end{array}$ & $\begin{array}{l}\text { ICAC can give control tasks: } \\
\text { - Professional Corporations of the } \\
\text { auditors; } \\
\text { - the selected physical persons according } \\
\text { to an objective process. } \\
\text { For } 2010 \text { and } 2011 \text { ICAC has made an } \\
\text { agreement with the Accounting and audit } \\
\text { Institute from Spain. }\end{array}$ \\
\hline $\begin{array}{l}\text { The surveillance of the } \\
\text { financial audit activity } \\
\text { according to the tasks } \\
\text { of the Directive } \\
43 / 2006 / \mathrm{CE}\end{array}$ & $\begin{array}{l}\text { The organism of public } \\
\text { surveillance of the financial audit } \\
\text { activity in Romania. }\end{array}$ & $\begin{array}{l}\text { The Accounting and Audit Institute in } \\
\text { Spain. }\end{array}$ \\
\hline Inspection terms & $\begin{array}{l}\text { - Minimum once in six years } \\
\text { - Minimum once in three years for } \\
\text { those who audit public interest } \\
\text { entities. }\end{array}$ & $\begin{array}{l}\text { - Minimum once in six years } \\
\text { - Minimum once in three years for those } \\
\text { who audit public interest entities. }\end{array}$ \\
\hline Qualifications & $\begin{array}{l}\text { A } \\
\text { B } \\
\text { C } \\
\text { D }\end{array}$ & $\begin{array}{l}\text { 2011 } \\
\text { Without } \\
\text { deficiencies } \\
\text { With deficiencies }\end{array}$ \\
\hline $\begin{array}{l}\text { Conditions for the } \\
\text { inspectors for quality } \\
\text { control }\end{array}$ & $\begin{array}{l}\text { - professional education and } \\
\text { relevant experience in statutory } \\
\text { audit } \\
\text { - specific preparation in quality } \\
\text { inspections; } \\
\text { - to be independent and not in the } \\
\text { interests conflict with the financial } \\
\text { auditor; } \\
\text { - a part of the members of the } \\
\text { control team are financial auditors. }\end{array}$ & $\begin{array}{l}\text { - professional education and seven years } \\
\text { experience audit } \\
\text { - specific preparation in quality } \\
\text { inspections; } \\
\text { - to be independent and not in the } \\
\text { interests conflict with the financial } \\
\text { auditor; } \\
\text { - they are not active auditors. }\end{array}$ \\
\hline
\end{tabular}

Source: self- processing 
In Romania, the development of the control works is done by the DMCP inspectors from CAFR and in Spain ICAC can name the control tasks to the Professional Corporations or to the physical persons selected during an objective process, being able to only supervise the work.

\section{The identification of some improvement possibilities of the quality control system of the financial audit in the two countries.}

a) In what Romania is concerned, it has adopted the International Standard of Quality Control (ISQC1) from the end of 2009.The adopting process and implementation of the internal quality control systems is quite difficult. In Spain, the three Professional Corporations play a fundamental part in the adjusting process of the audit firms at the tasks of the new International Norms of Quality Control (NCCI). These corporations have based special departments of quality in order to help its members to implement the new systems of quality. They have published guides, Manuals for organising and implementing of the quality control systems and have organised courses for professional practice.

I consider that these sustained activities of orientation of the financial auditors in their activity would be welcomed in Romania too. They would help implementing uniformly the new regulations and to clarifying the problems they face to. The wave of changes, the multitude of normative papers that come over night and have to be applied in a very short time occupy a big part of the attention and time of the specialist auditors.

b) If we analyse the ICAC Resolution from October 26th 2011 from Spain, we notice that the process of implementation of ISQC1 in this country has lasted more than two years. Spain had a Technical Norm of Quality Control from 1993 and there are specialists who say that there is not a big difference between this and the new NCCI (the translation and adjust of ISQC1). Other specialists say that it is about a new culture of quality, which needs time in order to be assimilated and properly implemented by the audit firms. That is why they have given it the necessary time and a special attention.

Therefore I underline the idea of introducing in Romania of a period of public consultation of the professional auditors in the case of introducing new audit norms.

c) The delay of entering into vigour of NCCI in Spain starting with January 1st 2013 has determined a confusion state among the auditors in this country, about WHEN starts the obligation of implementing the changes asked by the new ICAC. The norm itself does not specify any datum, the article being eliminated by ICAC. By the ICAC Resolution from 2010 it is fixed as a limit datum October 12th 2012, which lately it is modified by the Resolution from 2011 for January 1st 2013.

To my opinion, NCCI had to be implemented immediately after its publishing in December 2010 no matter the modifications that might have occurred after that during the six months period of public consultation. The implementation period expires at January $1^{\text {st }} 2013$. All this time, in case of some inspections from ICAC or of the Professional Corporations, in the case of identifying some deficiency in implementing the norms, this cannot be considered a bad thing to be punished, but there could be formulated recommendations for the correct implementation. The problem is that this system cannot be implemented in one day, being necessary sustained efforts for a long time, and starting January $1^{\text {st }} 2013$ all the audit firms in Spain have to have implemented the internal quality control system, its missing being a punishment reason.

d) The ICAC Resolution from 2010 states that once with entering into vigour of NCCI this will replace the Technical Quality Norm from 2003.

To the authors opinion Sonia M. Garcia Delgado and Izaskun Ipiñazar Petralanda expressed in the article "The audit in Spain before and after ISQC1 - a culture oriented towards 
quality", "there isn't a big difference" between the new NCCI and the old Technical Norm of Quality from 1993.

To my opinion, the content of the two norms doesn't have to be compared as they do not refer to the same problem. Once with emitting the Resolution ICAC from 2010, the Technical Norm of Quality from 1993 which refers to the quality control at the mission level was replaced by NCCI which refers to the quality control system at the audit firm level. It appears therefore a legislative hole that refers to the quality control which has to be applied by the auditors at the level of every audit firm. This replacement of the Technical Norm from 1993 had to be delayed up to the moment when enters into vigour ISA 220 in Spain. ISA 220 supposes the anterior implementation of ISQC1 into an audit firm, but this does not replace it. It is necessary the remaining into vigour of the Technical Norm of Quality from 1993 or the immediate adopting of ISA 220.

e) To my opinion the decision ICAC to expel from the NICC incidence the other services different from the financial audit, which are made by the auditors, it is not completely justified. I consider that this concept, "quality" should represent inside the audit cabinets a real culture, to be implemented to all the services they do. Moreover, in the case of audit firms of small and middle size the Quality Manual could not have a general character. Therefore to these it is imposed the elaboration of two quality books- one for audit missions and one for other activities. Therefore I consider that the missions of revise, assurance and side services (otros compromisos de aseguramiento y de otros servicios relacionados) had to be part of the present quality norm.

f) If we compare the external quality control system from the two countries we can notice the following particularity:

The Financial Auditors Chamber from Romania (CAFR) is the professional organism which "organises, coordinates and authorises the development of the activity of financial audit in Romania" (O.U.G. 75/1999). The same it is in Spain, these activities are realised by the Accounting and Audit Institute (ICAC).

In Romania, the external quality control activity for the financial audit and the financial auditors is realised by the Department of Monitories and Professional Competence from CAFR, and the supervising activity for CAFR, as it is stated in the Directive 2006/43/CE is done by the Public Surveillance Organism for the Financial Audit Activity.

In Spain has not been created another organism to supervise the ICAC activity, but they had as an option the fact that ICAC should give the tasks as external quality control for the audit firms to the Professional Corporations or to some especially authorised persons for the matter, and the supervising activity it is made by the Accounting and Audit Institute (ICAC).

\section{Conclusions}

The hypothesis of the research refers to the fact that in Romania and in Spain has been made important steps in adopting the reglementations of the European Directives referring the financial audit regarding the quality control, so that the juridical and professional frame of the two countries presents similitude, the differences being less significant.

The International Standard of the Quality Control (ISQC10 is being considered in this moment the most important pole in what concerns assuring the quality inside an audit firm. Adopting these norms in Romania starting 2009 represents a real performance. At the level of Spain it will enter into vigour later, starting January 2013, but its applying in some firms has started in 2010.

Though there are rhythm differences between the two countries concerning adopting international norms, it is important the orientation towards their acceptance, fact which will lead to the gradual unity of the financial audit at the European and International level.

The found differences between the systems of the quality control in Romania and Spain are not fundamental, because they have at the basic level the same principles. The European 
recommendations represent a general action frame and leave a large space to interfere the member states which generate different control degrees, revision and regulation.

Considering the above mentioned I consider that the hypothesis of research has been demonstrated. The similitude of the principles which are the basis of the national regulations in Romania and Spain concerning the quality control, make that the found differences to be more like form ones than fond ones, being therefore insignificant.

As future research lines I would remark the possibility of realising a comparative study between Romania and Spain regarding the evolution of the number of the quality controls made in the last years or of the system of fees applied to the financial auditors and to the audit firms in the two countries, as a result of the activity of quality control.

"The last two decades have represented a period of great changes in the bussiness environment" (Tabără, Briciu, 2012) and as a result the financial audit could not remain still. On the contrary, it had to be one step foreward, to give confidence in the market transactions."The XXIst century is considered, justified, the century of the revolution in performance in which will be on the top the management and the audit of the performance...”(Tabără, Briciu, 2012) . The globalisation phenomenon and the world economic crises which has started in 2008 have influenced and will influence the structure and the content of the legislation concerning the financial audit.

\section{References}

1. Cantwell C., 2010. Considerations regarding the quality control of the firms, The Financial Audit,, 11, pp. 37-40

2. Ceberio Ortuzar J., 2011. La nueva Norma de Control de Calidad Interno: un paso adelante en la profesion de auditoria, Auditores Magazine, 15, pp. 31-33

3. Fernández J.A., 2011. Normative Comments on the International Norm of Quality Control, Auditores Magazine, 14, pp. 58-65

4. Garcia Delgado S., Izaskun Ipiñazar P., 2011. La auditoría en España: un antes y un despues de la ISQC1 - una cultura orientada a la calidad, Revista Partida Doble, pp. 13

5. Instituto de Cesores Jurados de Espana, 2011. Comentarios normativos sobre las Normas Tecnicas de Auditoria, Revista Auditores,. 14, pp. 58-65

6. Neamțu H., Roman A.G., Țurlea E., 2012. Financial Audit- assurance missions and side services, Economica Publishing House, Bucharest

7. Puig de Travy C., 2010. El Control de la Calidad en el marco de la nueva LAC, Zaragoza, www.rea.economistas.es

8. Tabără N., Briciu S., 2012. News and perspectives in accounting and market control, Tipo Moldova Publishing House, Iaş

9. The European Economic and Social Committee, 2011. Audit Policy: Lessons from the crises, Green Paper published in the Official Journal of the European Union nr. 248/92 from August $28^{\text {th }} 2011$, available at http://eur-lex.europa.eu

10. The Accountants International Federation, 2009. International Audit Standards and quality control, 2009, Irecson Publishing House, Bucharest

11. The Accountants International Federation, 2008. International audit regulations, assurance and ethics; financial audit, 2008, Irecson Publishing House, Bucharest

12. The Chamber of the Financial Auditors in Romania, 2012. A Guide for quality audit, Bucharest

13.Toma M., 2009. Initiation in the audit of the financial situation of an entity, the IIIrd edition revised and enlarged, CECCAR Publishing House, Bucharest 
14. Uyarra Encalado E., 2011. La puesta en marcha de la norma interna de control de calidad en los despachos de auditoria, Revista Partida Doble, 234, pp. 85-89

15. ***, Law nr. 19 from July 12th 1988 regarding the financial audit from Spain published in B.O.E. nr. 169/ July 15 th 1988

16. ***, Law nr. 12/2010 regarding the modification and complete the law 19 from July $12^{\text {th }}$ 1988, published in BOE. no. 159/ July 1st 2010

17. ***, Law nr. 26 from 2010 to modify and complete O.U.G. nr. $75 / 1999$ regarding the activity of financial audit From Romania, published in Official Monitor of Romania, Part I, nr. 145 from March 5th 2010

18. ***, Emergency Ordinance of Government.of Romania (OUG) no. 75/1999 regarding the financial activity of audit from Romania republished in Official Monitor of Romania nr. 67, august 31 st 2002

19. ***, Emergency Ordinance of Government.of Romania (OUG) no. 90/2008 regarding the statutory audit for the annual financial situations and for the consolidated annual financial situations, published in the Official Monitor of Romania nr. 481 from June 30th 2008

20. ***, Real Decreto nr. 1636/1990 which approves the Regulations of functioning the law nr. 19/1988, published in December 20th 1990

21. ***, The revised text of the Financial Audit Law (TRLAC), approved by Real Decretory nr. 1/2011, published in B.O.E. nr. 157 from July 2nd 2011

22. ***, The applying regulation of TRLAC, approved by Real Decretory Legislative nr. 1, from July 2011, published in B.O.E. no. 266 from November 4th 2011 